\title{
Genetic polymorphisms of patients on stable warfarin maintenance therapy in a Ghanaian population
}

\author{
William Kudzi ${ }^{*}$, Samuel Yao Ahorhorlu' ${ }^{1}$ Bartholomew Dzudzor ${ }^{2}$,Edeghonghon Olayemi ${ }^{3}$, \\ Edmund Tetteh Nartey ${ }^{1}$ and Richard Harry Asmah ${ }^{4}$
}

\begin{abstract}
Background: Warfarin is a widely prescribed anticoagulant with narrow therapeutic window for thromboembolic events. Warfarin displays large individual variability in dose requirements. The purpose of this study is to assess the contribution of patient-specific and genetic risk factors to dose requirements of patients on either high or low warfarin maintenance dose in Ghana. Blood samples were collected from 141 (62 males, 79 females) Ghanaian patients on stable warfarin dose to determine their INR. Influence of patient specific factors and gene variations within VKORC1, CYP2C9 and CYP4F2 were determined in patients on either high or low warfarin maintenance dose.
\end{abstract}

Results: One hundred and forty-one patients took part in the study with 79 (56\%) participants being Female. The median age of the study participants was 48 years [IQR: 34-58]. The median duration for patients to be on warfarin therapy was 24 months [IQR: 10-72]. Majority of the study participants $(80.9 \%, n=114)$ did not have any side effects to warfarin. CYP2C9*2 and CYP2C9*3 variant alleles were not detected. VKORC1 variant allele was observed at $6 \%$ and CYP4F2 variant allele was observed at 41\%. Duration of patients on warfarin therapy was marginally associated with high warfarin dose (adjusted $\mathrm{OR}=1.01$ [95\% $\mathrm{Cl} 1.00-1.02], \mathrm{p}=0.033$ ) while the odds of heterozygous individuals (G/A) for VKORC1 gene to have high warfarin dose compared to persons with homozygous (G/G) (adjusted OR $=0.06$ [95\% Cl 0.01-0.63], $\mathrm{p}=0.019$ ). Age, gender, diagnosis, presence of side effects and other medications were not associated with warfarin dose $(p=0.05)$.

Conclusion: This study provides data on VKORC1 and CYP4F2 variants among an indigenous African population. Duration of patients on warfarin therapy was marginally associated with high warfarin dose. CYP2C ${ }^{*} 2$ and *3 variants were not detected and may not be the most important genetic factor for warfarin maintenance dose among Ghanaians.

Keywords: Warfarin, Allele frequencies, CYP2C9, CYP4F2, VKORC1, Pharmacogenetics

\section{Background}

Warfarin is an oral anticoagulant agent used worldwide for preventing and managing thromboembolic events that often give rise to stroke, deep vein thrombosis (DVT) and pulmonary embolism (PE). It is also used following heart valve replacements and atrial fibrillation (AF) [1].

\footnotetext{
*Correspondence: wkudzi@yahoo.com

${ }^{1}$ Centre for Tropical Clinical Pharmacology and Therapeutics, School of Medicine and Dentistry, College of Health Sciences, University of Ghana, P.O. GP 4236, Accra, Ghana

Full list of author information is available at the end of the article
}

The use of Warfarin has increased over the last 15 years, especially among the elderly population [2]. Warfarin has a narrow therapeutic range which varies among individual patients making selection of the right warfarin dose at the onset of treatment challenging. An appropriate warfarin dose in one patient may induce a haemorrhagic event in another. Clinical factors, demographic variables, and variations in genes contribute significantly to the variable warfarin dose requirements among patients [3].

It is estimated that $1 \%$ of patients die due to bleeding complications associated with warfarin and up to $15 \%$ 
of patients experience minor bleeding complications [4]. The efficacy of warfarin is dependent on maintaining a patient's anticoagulation within acceptable therapeutic range without the risk of bleeding. The effectiveness and safety of warfarin is dependent on maintaining the international normalized ratio (INR), within the recommended therapeutic range of 2.0 and 3.0 for most conditions and 2.5 and 3.5 following heart valve replacements [5].

This large variation in warfarin dose requirements among patients may be due to concomitant medications, gender, nutritional status, alcohol consumption, liver disease, hyperthyroidism, Congestive heart failure and variations in genes [3].

Several studies have indicated that elderly patients require lower warfarin doses compared to younger ones [6] while women require lower warfarin dose [7]. Recent studies have also suggested that populations from the African American require more warfarin to maintain their INR between 2 and 3 than do Caucasians $[5,8]$.

Pharmacogenomics research on warfarin has focused on vitamin $\mathrm{K}$ epoxide reductase (VKORC), Cytochrome P450 isozyme 2C9 (CYP2C9), and Cytochrome P450 isozyme 4F2 (CYP4F2) genes [9]. Warfarin is a racemic mixture of $\mathrm{R}$ - and S-enantiomers. The $\mathrm{S}$-warfarin enantiomer is more potent and is metabolized in the liver by CYP2C9 enzyme [10]. CYP2C9*2 (430C $>\mathrm{T}$ and rs $1,799,853)$ and CYP2C9*3 $(1075 \mathrm{~A}>\mathrm{C}$ and rs $1,057,910)$ are common variants known to decrease warfarin maintenance dose requirement in patients. $C Y P 2 C 9^{*} 2$ and $C Y P 2 C 9 * 3$ variant alleles have been reported at 3.3 and 2.3\% respectively in African American populations [11]. CYP2C9*2 variant allele has rarely been reported in Asian populations while the $C Y P 2 C 9 * 3$ variant allele was prevalent at $1.1-6.8 \%$ within the Asian populations [12]. Patients carrying CYP2C9*2 and $C Y P 2 C 9 * 3$ alleles potentially have a greater risk of bleeding during initiation of warfarin and subsequently require lower doses [13]. Many studies have shown the use of CYP2C9 polymorphism as being helpful in optimizing the administration of warfarin $[13,14]$.

Cytochrome P450-4F2 (CYP4F2) gene also contributes $1-2 \%$ of warfarin dose variability and impact on stable warfarin dose [15]. Patients with two variant TT alleles of CYP4F2, (p. V433M and rs 2,189,784), will require approximately $1 \mathrm{mg}$ /day more of warfarin than those who carry two wild type CC alleles [16].

The anticoagulant activity of warfarin is due to inhibition of the vitamin $\mathrm{K}$ epoxide reductase complex subunit 1 (VKORC1) enzyme which reduces the regeneration of vitamin $\mathrm{K}$ and thus exerting its anticoagulation effect. Polymorphism of g.-1639G > A (rs 9923231) within $V K O R C 1$ promoter reduces the expression of the gene and therefore lowers the amount of VKORC and leads to warfarin sensitivity. Variations in VKORC1 have been associated with both warfarin sensitivity and warfarin resistance. The prevalence of VKORC1 polymorphism has been reported in literature as $37 \%$ for Caucasians and $14 \%$ for Africans [8]. CYP2C9 and VKORC1 polymorphisms occur frequently in patients who are warfarin "sensitive" and require lower doses, whereas patients with $V K O R C 1$ missense mutations are warfarin "resistant" and require higher doses [17]. CYP2C9*2, CYP2C9*3 and $V K O R C 1$ promoter mutation together is estimated to account for $40-63 \%$ of the variability in therapeutic warfarin dose $[8,18]$. Combination of genetic and other clinical factors to predict the warfarin maintenance dose may be more accurate than using clinical factors alone [19].

Clinical testing of drugs and majority of clinical research are performed in Europe and the USA where individuals of African descent are in minority and the populations are underrepresented in these research activities [20]. Paying attention to pharmacogenomics research in Sub-Saharan African population is particularly important because of the increasing numbers of communicable diseases such as HIV/AIDS and noncommunicable diseases such as hypertension. Pharmacogenetic data among the indigenous African population is scarce and there is currently no pharmacogenetic data on warfarin metabolism among the Ghanaian population. Allele frequencies among different ethnic patient populations vary and are unclear. Frequencies of $C Y P 4 F 2$, CYP2C9 and VKORC1 among indigenous African populations have not been systematically established. This study seeks to determine how various patient specific factors impact management of warfarin dose in Korle-bu Teaching Hospital. The study also sought to determine and compare the impact of polymorphisms of CYP2C9, VKORC1 and CYP4F2 on patients on either low or high warfarin maintenance dose in Ghana.

\section{Methods \\ Subjects}

The study population comprised of 141 (62 males, 79 females) stable warfarin patients recruited mainly from the Cardiothoracic Center of the Korle-bu Teaching (KBTH) in Accra, Ghana. The Cardiothoracic Center screens about 220 patients a week and all adults patients (18 years and above) who were on warfarin therapy were eligible for recruitment into the study. These eligible patients were screened by a Clinician and only warfarin patients whose warfarin dose requirement remained stable for at least 3 previous clinic visits over a minimum period of 3 months, with INR within the range of 2.03.0, were included in the study. Warfarin patients with unstable dose requirement, with target INR outside the 
range, were deem as noncompliant to warfarin therapy and were excluded from the study. Ethical and Protocol Review Committee of School of Medicine and Dentistry, University of Ghana, approved this study with reference number MS-Et/M.6-P.4.5/2011-2012. Written informed consent was obtained from all patients prior to inclusion in the study.

Patients between 17 and 77 years of age receiving warfarin and attending clinics for permanent Atrial Fibrillation/Flutter, Left atrial or ventricular thrombus, Deep Vein Thrombosis, Pulmonary Embolism, Heart Valve Replacement (Mechanical or Biological with AF), Cardiomyopathy (Ischemic or Dilated), and Peripheral Vascular Disease were enrolled for the study. Patients with the following medical conditions; history of gastro-intestinal (GI) bleeding or peptic ulcer disease, significant liver disease (active hepatitis or chronic hepatitis B or $\mathrm{C}$ virus (HBV/HCV) infection), uncontrolled hypertension, chronic diarrhoea or malabsorption syndrome, viral or bacterial infection prior to enrolment, active or previous infective endocarditis, hospital stay $>30$ days as a result of septicaemia, mediastinitis or pneumonia, cardiac cachexia, and morbid obesity were excluded from the study.

Patient information such as age, gender, clinical history for warfarin dose, present INR, additional medical problems and all other medications were collected retrospectively from chart reviews. Height and weight were measured to calculate body mass index (BMI) for all patients.

Patients were classified as being on either a high or low depending on their daily warfarin maintenance doses to determine areas where the two populations differed [21]. High daily warfarin dose was defined as $>5 \mathrm{mg}$ /daily and a low daily warfarin dose was defined as $\leq 5 \mathrm{mg} /$ daily based on common practice already available in Korle-Bu Teaching Hospital.

Eighty-four (84) of these patients were on low daily warfarin maintenance dose and fifty-seven (57) of these patients were on high daily warfarin maintenance dose. Blood sample $(3 \mathrm{ml})$ was taken from all participating patients for INR measurement and for CYP2C9, VKORC1 and CYP4F2 genotyping.

\section{DNA extraction and genotyping genomic}

DNA was isolated from $1.5 \mathrm{ml}$ of whole blood sample collected in tubes containing ethylenediaminetetraacetic acid (EDTA) and stored at $4{ }^{\circ} \mathrm{C}$ using a QIAamp DNA blood Maxi Kit (Qiagen, Crawley UK), following the manufacturer's protocol. $C Y P 2 C 9^{*} 2$ and $C Y P 2 C 9^{*} 3$ variant alleles were analysed using Polymerase Chain Reaction-Restriction Fragment Length Polymorphism (PCR-RFLP) as previously described by Burian et al. [22] with some modifications. CYP2C9 allele ("1) was assigned as the wild-type in the absence of other detectable variant alleles. The presence of VKORC1 (rs $9,923,231$ ) variant allele was determined by PCR-RFLP as previously described by Aomori et al. [23] and CYP4F2 (rs 2,108,622) variant allele determined as described by Cen et al. [9].

All PCRs were carried out in $25 \mu \mathrm{l}$ final volume containing $0.5 \mathrm{~g}$ genomic DNA, $0.025 \mu \mathrm{M}$ forward and reverse primers and $12.5 \mu \mathrm{l}$ of $2 \times$ Taq Super mix $(400 \mu \mathrm{M}$ dNTPs, $1.5 \mathrm{mM} \mathrm{Mg}^{2+}, 1 \mathrm{U}$ Taq polymerase) (BioPioneer, USA). Details of primer sequences, amplicon sizes and restriction enzymes for CYP2C9, CYP4F 2 and VKORC1 are shown in Table 1. PCR cycling condition for $C Y P 2 C 9^{*} 2$ allele consisted of initial denaturation step of $95^{\circ} \mathrm{C}$ for $10 \mathrm{~min}$, followed by 45 cycles $\left(95^{\circ} \mathrm{C}\right.$ for $5 \mathrm{~s}$, $53{ }^{\circ} \mathrm{C}$ for $10 \mathrm{~s}, 72{ }^{\circ} \mathrm{C}$ for $15 \mathrm{~s}$ ) and final extension at $72{ }^{\circ} \mathrm{C}$ for 5 min. Cycling condition for CYP2C9*3 allele carried out at an initial denaturation step of $5 \mathrm{~min}$ at $94{ }^{\circ} \mathrm{C}$, followed by 30 cycles $\left(94{ }^{\circ} \mathrm{C}\right.$ for $45 \mathrm{~s}, 53{ }^{\circ} \mathrm{C}$ for $45 \mathrm{~s}$, and $72{ }^{\circ} \mathrm{C}$ for $1 \mathrm{~min}$ ) with a final extension for $5 \mathrm{~min}$ at $72{ }^{\circ} \mathrm{C}$. The amplifications for CYP4F2 (rs 2,108,622) consisted of an initial denaturation step at $95^{\circ} \mathrm{C}$ for 5 min followed by 35 amplification cycles $\left(94{ }^{\circ} \mathrm{C}\right.$ for $30 \mathrm{~s}, 50{ }^{\circ} \mathrm{C}$ for $30 \mathrm{~s}$ and $72{ }^{\circ} \mathrm{C}$ for $1 \mathrm{~min}$ ) and a final incubation at $72{ }^{\circ} \mathrm{C}$ for $7 \mathrm{~min}$. The amplifications for $V K O R C 1$, initial denaturation step of $5 \mathrm{~min}$ at $95^{\circ} \mathrm{C}$, followed by 35 cycles $\left(95^{\circ} \mathrm{C}\right.$ for $1 \mathrm{~min}$, $51{ }^{\circ} \mathrm{C}$ for $30 \mathrm{~s}$, and $72{ }^{\circ} \mathrm{C}$ for $2 \mathrm{~s}$ ) with a final extension for 10 min at $72{ }^{\circ} \mathrm{C}$. Blank tubes without DNA were included in each batch of samples analysed as control.

The resulting PCR products were digested with appropriate restriction enzymes (Table 1). All digested products were visualized on $2.5 \%$ agarose gels stained with ethidium bromide. A few randomly selected samples of genotypes were sequenced for confirmation of assays after restriction digests.

\section{Statistical analysis}

All data were entered into Statistical Package for Social Science (ver.17.0; SPSS, Chicago, IL) and imported into Stata $^{\text {TM }}$ version 10 (StataCorp, College Station, Texas, United States) for statistical analyses. Descriptive statistics were calculated for patients on both high and low warfarin dose. Data were summarized as frequencies and proportions. Genotype deviations from the HardyWeinberg equilibrium were determined. Chi-square tests were performed to test for association between categorical variables. Warfarin dosages were summarized as means with accompanying standard deviations, and compared between patients of different genotypes using $t$ tests and analysis of variance (ANOVA). All reported $p$ values were two-sided and considered statistically significant at a level of $\mathrm{p}<0.05$. 
Table 1 Primer sequences

\begin{tabular}{|c|c|c|c|c|}
\hline & Sequences & Amplicon size & Restriction enzyme & Reference \\
\hline \multicolumn{5}{|l|}{ CYP2C9*2 } \\
\hline Forward & 5'-CACTGGCTGAAAGAGCTAACAGAG-3' & $375 \mathrm{bp}$ & Avall & [22] \\
\hline Reverse & 5'-GTGATATGGAGTAGGGTCACCCAC-3' & & & \\
\hline \multicolumn{5}{|l|}{$\mathrm{CYP} 2 \mathrm{CP}^{*} 3$} \\
\hline Forward & 5'-TGCACGAGGTCCAGAGGTAC-3' & $105 \mathrm{bp}$ & Kpnl & {$[22]$} \\
\hline Reverse & 5'-ACAAACTTACCTTGGGAATGAGA-3' & & & \\
\hline \multicolumn{5}{|l|}{ CYP4F2 } \\
\hline Forward & 5'-CGGAACTTGGACCATCTACA-3' & $439 \mathrm{bp}$ & Pvull & {$[14]$} \\
\hline Reverse & 5'-CCTACTCTCCCACAGGCATTA-3' & & & \\
\hline \multicolumn{5}{|l|}{ VKORC1 } \\
\hline Forward & 5'-ATCCCTCTGGGAAGTCAAGC-3' & $636 \mathrm{bp}$ & Ncil & [23] \\
\hline Reverse & 5'-САССТTCAACCTCTCCATCC--3' & & & \\
\hline
\end{tabular}

\section{Results and discussions}

\section{Patient characteristics}

Table 2 summarizes the baseline socio-demographics and clinical characteristics of the 141 patients who consented to take part in the study. The median age of the study participants was 48 years [IQR: 34-58]. Female participants were $79(56 \%)$ and the most common indications for

Table 2 Socio-demographic and clinical characteristics of 141 patients administered warfarin at Korle-bu Teaching Hospital in Accra

\begin{tabular}{lc}
\hline Characteristic & Frequency, \% \\
\hline Age (years) $(\mathrm{N}=141)$ & $48(34-58)$ \\
Median (inter-quartile range) & \\
Gender $(\mathrm{N}=141)$ & $79(56.0)$ \\
Female & \\
Body mass index $(\mathrm{N}=141)$ & $55(39.0)$ \\
Normal (18.00-24.99 $\left.\mathrm{kg} / \mathrm{m}^{2}\right)$ & $86(61.0)$ \\
Overweight/Obese $\left(\geq 25.00 \mathrm{~kg} / \mathrm{m}^{2}\right)$ & \\
Warfarin duration (months) $(\mathrm{N}=139)$ & $24(10-72)$ \\
Median (inter-quartile range) & \\
Diagnosis (N=140) & $63(45.0)$ \\
Mitral valve replacement & $51(36.4)$ \\
Deep vein thrombosis & $10(7.2)$ \\
Atrial fibrillation & $16(11.4)$ \\
Pulmonary embolism & \\
Presence of side effects $(\mathrm{N}=141)$ & $27(19.1)$ \\
Yes & $114(80.9)$ \\
No & $76(53.9)$ \\
Other medication given $(\mathrm{N}=141)$ & $65(46.1)$ \\
Yes & \\
No & \\
\hline$N$ number of study participants &
\end{tabular}

warfarin use were valve replacement $(n=63,45 \%)$, deep vein thrombosis $(\mathrm{n}=51,36.4 \%)$, pulmonary embolism $(\mathrm{n}=16,11.4 \%)$, and atrial fibrillation $(\mathrm{n}=10,7.20 \%)$. The median duration for patients to be on warfarin therapy was 24 months [IQR: 10-72]. Majority of the study participants $(80.9 \%, \mathrm{n}=114)$ did not have any adverse reaction to warfarin.

Allele and genotype frequencies for $C Y P 2 C 9, C Y P 4 F 2$ and $V K O R C 1$ variants genotyped are summarized in Table 3. A total of 141 samples were collected for analysis, however, between 87 and 116 were available for each single nucleotide polymorphism. All the genotypes were in Hardy-Weinberg equilibrium. CYP2C9*2, and CYP2C9*3 variant alleles were not detected in any of the patients genotyped in this study population. This is consistent with data from an earlier study among Ghanaians [24] and Beninese population [25]. Frequencies of VKORC1 allele A was observed at $6.2 \%$ which is similar to that reported for Mozambicans (3.5\%) [26] and African-Americans (10.8\%) [27]. It is however lower than that reported for Asians (66.7\%), Caucasians (40.6\%), Hispanics (43.6\%) [17] and Ashkenazi Jewish (46.7\%) populations [28]. CYP2C9*5, *6, *8, *11 variants occur individually in relatively low allele frequencies among African populations and have been associated with warfarin dose. These variants were not analyzed in this study, homozygous $C Y P 2 C 9 * 1$ or heterozygous $C Y P 2 C 9 * 1$ were therefore considered putative. An earlier study among Ghanaian population did not detect CYP2C9*5 but reported $C Y P 2 C 9^{*} 11$ with the frequency of $2 \%$ [24].

VKORC1 (A) variant allele was detected to be $12(6.2 \%)$ while those for VKORC1 (G) was observed at $180(93.8 \%)$ in population studied. Eighty-four patients $(87.5 \%)$ were homozygous wild-type (G/G) for VKORC1 while 12 $(12.5 \%)$ patients were heterozygous (G/A). Homozygous 
Table 3 Allele and Genotype frequencies (VKORC1, CYP4F2, CYP2C9*2 and CYP2C9*3) of patients administered warfarin at Korle-bu Teaching Hospital in Accra

\begin{tabular}{|c|c|}
\hline Genetic characteristic & Frequency, $\%$ \\
\hline \multicolumn{2}{|l|}{ VKORC1 $(\mathrm{N}=96)$} \\
\hline \multicolumn{2}{|l|}{ Gene } \\
\hline GG (wild type) & $84(87.5)$ \\
\hline GA & $12(12.5)$ \\
\hline AA & - \\
\hline \multicolumn{2}{|l|}{ Allele } \\
\hline G & $180(93.8)$ \\
\hline A & $12(6.2)$ \\
\hline \multicolumn{2}{|l|}{ CYP4F2 $(N=116)$} \\
\hline \multicolumn{2}{|l|}{ Gene } \\
\hline CC (wild type) & $28(24.1)$ \\
\hline$C T$ & $80(69.0)$ \\
\hline TT & $8(6.9)$ \\
\hline \multicolumn{2}{|l|}{ Allele } \\
\hline C & $136(58.6)$ \\
\hline T & $96(41.4)$ \\
\hline \multicolumn{2}{|l|}{$C Y P 2 C 9 * 2(N=86)$} \\
\hline \multicolumn{2}{|l|}{ Gene } \\
\hline CC (wild type) & $86(100)$ \\
\hline $\mathrm{CT}$ & - \\
\hline TT & - \\
\hline \multicolumn{2}{|l|}{ Allele } \\
\hline$C$ & $172(100)$ \\
\hline T & - \\
\hline \multicolumn{2}{|l|}{ CYP2C9*3 $(\mathrm{N}=84)$} \\
\hline \multicolumn{2}{|l|}{ Gene } \\
\hline AA (wild type) & $84(100)$ \\
\hline$A C$ & - \\
\hline $\mathrm{CC}$ & - \\
\hline \multicolumn{2}{|l|}{ Allele } \\
\hline A & $168(100)$ \\
\hline C & - \\
\hline
\end{tabular}

CYP2C9, CYP4F2 and VKORC1 were the genes genotyped. CYP2C9*2 and CYP2C9*3 were not detected. Homozygous CYP2C9*1 or heterozygous CYP2C9*1 were considered putative since we did not genotype for the rest of the other allelic variants

$N$ number of study participants, $A$ adenine, $G$ guanine, $C$ cytosine, $T$ thymidine

variant (A/A) was not detected in the study population and this is consistent with previous studies which reported that this genotype is very rare (1\%) in Africans [29]. This observation however differed from that reported among Asians (55.9\%), Caucasians (17.9\%), Hispanics (17.8\%) and Ashkenazi Jewish (22.7\%) populations [27, 28].
Allele frequencies for $C Y P 4 F 2(\mathrm{~T})$ was observed at $96(41.4 \%)$ while that of the wild-type (G) allele was observed at 136 (58.6\%). This observation is higher than that reported in African-Americans (11.7\%), Asians (30.5\%), Caucasians (34.2\%), Hispanics (23.3\%) and Ashkenazi Jewish (32.8\%) populations [17]. For the CYP4F2, 28 (24.1\%) patients were found to be homozygous wild-type $(\mathrm{C} / \mathrm{C}), 80$ (69\%) patients were heterozygous for $\mathrm{C} / \mathrm{T}$, and $8(6.9 \%)$ patients were homozygous mutant for $\mathrm{T} / \mathrm{T}$.

Patients were classified as being on either a high or low depending on their daily warfarin maintenance doses to determine areas where the two populations differed [21]. Eighty-four $(59.6 \%)$ patients were on low daily warfarin maintenance dose $(\leq 5 \mathrm{mg} /$ daily) and fifty-seven $(40.4 \%)$ patients were on high daily warfarin maintenance dose ( $>5 \mathrm{mg} /$ daily). For female patients, 33 (57\%) were on high warfarin dose while 46 (54.8\%) were on low maintenance dose. In a multivariate analysis, duration of patients on warfarin therapy and $V K O R C 1$ gene was associated with warfarin dose classification. Duration of patients on warfarin therapy was marginally associated with high warfarin dose (adjusted OR $=1.01$ [95\% CI 1.00-1.02], $\mathrm{p}=0.033)$ while the odds of heterozygous individuals (G/A) for $V K O R C 1$ gene to have high warfarin dose, compared to individuals with the homozygous (G/G) (adjusted OR $=0.06$ [95\% CI 0.01-0.63], p $=0.019$ ) compared to individuals with the homozygous (G/G). Age, gender, diagnosis, presence of side effects and other medications were not associated with warfarin dose $(\mathrm{p}=0.05)($ Table 4).

\section{Limitations}

The study may not have been adequately powered to detect statistically significant differences between patient-specific factors. Allele frequencies of $C Y P 2 C 9 * 5$, "6, "8, and "11 were not determined in this study due to limitation of resources. Data on patients with unstable warfarin dose and target INRs outside therapeutic range which could have been used as a validation cohort was not collected in this study.

\section{Conclusion}

This study provides data on VKORC1 and CYP4F2 variants in an indigenous African population. Duration of patients on warfarin therapy was marginally associated with high warfarin dose. CYP2C $2 * 2$ and " 3 variants were not detected and may not be the most important genetic factor for warfarin maintenance dose among Ghanaians. 
Table 4 Factors associated with high warfarin dosage in patients administered warfarin at Korle-bu Teaching Hospital in Accra

\begin{tabular}{|c|c|c|c|c|c|c|}
\hline \multirow[t]{4}{*}{ Characteristic } & \multicolumn{2}{|c|}{ Dosage classification } & \multirow[t]{4}{*}{ Crude OR $[95 \% \mathrm{Cl}]$} & \multirow[t]{4}{*}{$p$ value } & \multirow[t]{4}{*}{ Adjusted OR $[95 \% \mathrm{Cl}]^{\mathrm{a}}$} & \multirow[t]{4}{*}{ p value } \\
\hline & High & Low & & & & \\
\hline & $N=57$ & $N=84$ & & & & \\
\hline & $n, \%$ & $n, \%$ & & & & \\
\hline Age (years) (median, interquartile range) & $46(33.0-57.0)$ & $48(36.8-59.0)$ & $0.99[0.96-1.01]$ & 0.298 & $0.99[0.96-1.03]$ & 0.770 \\
\hline $\begin{array}{l}\text { Warfarin duration (months) (median, interquartile } \\
\text { range) }\end{array}$ & $24(11-99)$ & $24(8-61)$ & $1.00[1.00-1.01]$ & 0.062 & $1.01[1.00-1.02]$ & 0.033 \\
\hline \multicolumn{7}{|l|}{ Gender } \\
\hline Female & $33(57.9)$ & $46(54.8)$ & $1.14[0.58-2.24]$ & 0.713 & $1.05[0.40-2.71]$ & 0.928 \\
\hline Male & $24(42.1)$ & $38(45.2)$ & 1.00 & & & \\
\hline \multicolumn{7}{|l|}{ Body mass index } \\
\hline Overweight & $33(57.9)$ & $53(63.1)$ & $0.80[0.40-1.60]$ & 0.535 & - & - \\
\hline Normal & $24(42.1)$ & $31(36.9)$ & 1.00 & & & \\
\hline \multicolumn{7}{|l|}{ Diagnosis } \\
\hline Deep vein thrombosis & $21(936.8)$ & $30(36.2)$ & $1.00[0.47-2.11]$ & 0.992 & - & - \\
\hline Atrial fibrillation & $2(3.5)$ & $8(9.6)$ & $0.36[0.07-1.81]$ & 0.214 & - & - \\
\hline Pulmonary embolism & $8(14.1)$ & $8(9.6)$ & $1.42[0.47-4.28]$ & 0.530 & - & - \\
\hline Mistral valve replacement & $26(45.6)$ & $37(44.6)$ & 1.00 & & & \\
\hline \multicolumn{7}{|l|}{ Presence of side effects } \\
\hline Yes & $11(19.3)$ & $16(19.1)$ & $1.02[0.43-2.39]$ & 0.970 & - & - \\
\hline No & $46(80.7)$ & $68(80.9)$ & 1.00 & & & \\
\hline \multicolumn{7}{|l|}{ Other medications given } \\
\hline Yes & $30(52.6)$ & $46(54.8)$ & $0.92[0.47-1.80]$ & 0.803 & - & - \\
\hline No & $27(47.4)$ & $38(45.2)$ & 1.00 & & & \\
\hline \multicolumn{7}{|l|}{ VKORC1 } \\
\hline GA (heterozygous) & $1(2.6)$ & $11(19.0)$ & $0.12[0.01-0.94]$ & 0.043 & $0.06[0.01-0.63]$ & 0.019 \\
\hline GG (Wild type) & $37(97.4)$ & $47(81.0)$ & 1.00 & & 1.00 & \\
\hline \multicolumn{7}{|l|}{ CYP4F2 } \\
\hline TT (mutant) & $5(9.6)$ & $3(4.7)$ & $3[0.59-15.26]$ & 0.186 & $5.47[0.61-48.79]$ & 0.128 \\
\hline CT (heterozygous) & $37(71.2)$ & $43(67.2)$ & $1.55[0.64-3.77]$ & 0.335 & $1.91[0.54-6.80]$ & 0.317 \\
\hline CC (wild type) & $10(19.2)$ & $18(28.1)$ & 1.00 & & 1.00 & \\
\hline
\end{tabular}

OR odds ratio, $\mathrm{Cl}$ confidence interval

a Variables with $\mathrm{p}$ value $<0.02$ were entered into the multivariate model in addition to the gene variants VKORC1 and CYP4F2, age, gender and duration on warfarin medication

\section{Abbreviations}

INR: international normalized ratio; VKORC1: vitamin K epoxide reductase complex subunit 1; CYP2C9: cytochrome P450 isozyme 2C9; CYP4F2: cytochrome P450 isozyme 4F2; DVT: deep vein thrombosis; AF: atrial fibrillation; HIV: human immunodeficiency virus; AIDS: acquired immune deficiency syndrome; HBV: hepatitis B virus; HCV: hepatitis C virus; BMl: body mass index; KBTH: Korle-bu Teaching Hospital; EDTA: ethylenediamine tetraacetic acid; PCR: polymerase chain reaction; RFLP: restriction fragment length polymorphism.

\section{Authors' contributions}

WK conceived and designed the study. He also assisted in drafting the manuscript. SYA collected the clinical data and performed all the experimental analysis. DB and ARH supervised the experimental analysis and assisted in the interpretation of the results. EO profiled the patients and assisted in sample collection. NET assisted with the data analysis and drafting of the manuscript. All authors read and approved the final manuscript.

\begin{abstract}
Author details
${ }^{1}$ Centre for Tropical Clinical Pharmacology and Therapeutics, School of Medicine and Dentistry, College of Health Sciences, University of Ghana, P.O. GP 4236, Accra, Ghana. ${ }^{2}$ Department of Medical Biochemistry, School of Biomedical and Allied Health Sciences, College of Health Sciences, University of Ghana, P.O. GP 143, Accra, Ghana. ${ }^{3}$ Department of Haematology, School of Medicine and Dentistry, College of Health Sciences, University of Ghana, P.O. GP 4236 , Accra, Ghana. ${ }^{4}$ Department of Medical Laboratory Sciences, School of Biomedical and Allied Health Sciences, College of Health Sciences, University of Ghana, P.O. GP 143, Accra, Ghana.
\end{abstract}

\section{Acknowledgements}

We thank Dr. Daniel Gyingiri Achel and all staff of the Applied Radiation Biology Centre of the Radiological and Medical Sciences Research Institute (RAMSRI), Ghana Atomic Energy Commission (GAEC) for their support during the laboratory analysis of the samples for this research work. We extend special thanks to Mr. Rudolf Mba Adaboro at GAEC for his help and support during the molecular biology assays of the samples. 


\section{Competing interests}

The authors declare that they have no competing interests.

\section{Availability of data and materials}

The datasets used and/or analysed during the current study available from the corresponding author on reasonable request.

\section{Ethics approval and consent to participate}

Ethical and Protocol Review Committee of School of Medicine and Dentistry, University of Ghana, approved this study with reference number MS-Et/M.6P.4.5/2011-2012. Written informed consent to participate in this study was obtained from all patients prior to inclusion in the study.

\section{Funding}

Study was funded by the authors.

Received: 4 August 2015 Accepted: 26 November 2016

Published online: 09 December 2016

\section{References}

1. Daly AK, King BP. Pharmacogenetics of oral anticoagulants. Pharmacogenetics. 2003:13(5):247-52.

2. van Walraven C, Hart RG, Connolly S, Austin PC, Mant J, Hobbs FD, Koudstaal PJ, Petersen P, Perez-Gomez F, Knottnerus JA, et al. Effect of age on stroke prevention therapy in patients with atrial fibrillation: the atrial fibrillation investigators. Stroke J Cereb Circ. 2009;40(4):1410-6.

3. Wadelius M, Chen LY, Lindh JD, Eriksson N, Ghori MJ, Bumpstead S, Holm L, McGinnis R, Rane A, Deloukas P. The largest prospective warfarintreated cohort supports genetic forecasting. Blood. 2009;113(4):784-92.

4. Takahashi H, Wilkinson GR, Nutescu EA, Morita T, Ritchie MD, Scordo MG, Pengo V, Barban M, Padrini R, leiri I, et al. Different contributions of polymorphisms in VKORC1 and CYP2C9 to intra- and inter-population differences in maintenance dose of warfarin in Japanese, Caucasians and African-Americans. Pharmacogenet Genom. 2006;16(2):101-10.

5. Ansell J. Long-term, secondary treatment of deep venous thrombosis: do we know the appropriate duration of treatment or therapeutic regimen? Curr Hematol Rep. 2004;3(5):355-6.

6. Baglin TP, Cousins D, Keeling DM, Perry DJ, Watson HG. Safety indicators for inpatient and outpatient oral anticoagulant care: [corrected] Recommendations from the British Committee for Standards in Haematology and National Patient Safety Agency. Br J Haematol. 2007;136(1):26-9.

7. Absher RK, Moore ME, Parker MH. Patient-specific factors predictive of warfarin dosage requirements. Ann Pharmacother. 2002;36(10):1512-7.

8. Rieder MJ, Reiner AP, Gage BF, Nickerson DA, Eby CS, McLeod HL, Blough DK, Thummel KE, Veenstra DL, Rettie AE. Effect of VKORC1 haplotypes on transcriptional regulation and warfarin dose. N Engl J Med. 2005:352(22):2285-93.

9. Cen HJ, Zeng WT, Leng XY, Huang $M$, Chen $X$, Li JL, Huang ZY, Bi HC, Wang $X D$, He YL, et al. CYP4F2 rs2108622: a minor significant genetic factor of warfarin dose in Han Chinese patients with mechanical heart valve replacement. Br J Clin Pharmacol. 2010;70(2):234-40.

10. Takahashi H, Echizen H. Pharmacogenetics of warfarin elimination and its clinical implications. Clin Pharmacokinet. 2001:40(8):587-603.

11. Dreisbach AW, Japa S, Sigel A, Parenti MB, Hess AE, Srinouanprachanh $\mathrm{SL}$, Rettie AE, Kim H, Farin FM, Hamm LL, et al. The Prevalence of CYP2C8, $2 \mathrm{C} 9,2 \mathrm{~J} 2$, and soluble epoxide hydrolase polymorphisms in African Americans with hypertension. Am J Hypertens. 2005:18(10):1276-81.

12. Garcia-Martin E, Martinez C, Ladero JM, Agundez JA. Interethnic and intraethnic variability of CYP2C8 and CYP2C9 polymorphisms in healthy individuals. Mol Diagn Ther. 2006;10(1):29-40.

13. Hillman MA, Wilke RA, Yale SH, Vidaillet HJ, Caldwell MD, Glurich I, Berg RL, Schmelzer J, Burmester JK. A prospective, randomized pilot trial of modelbased warfarin dose initiation using CYP2C9 genotype and clinical data. Clinl Med Res. 2005:3(3):137-45.

14. Caraco Y, Blotnick S, Muszkat M. CYP2C9 genotype-guided warfarin prescribing enhances the efficacy and safety of anticoagulation: a prospective randomized controlled study. Clin Pharmacol Ther. 2008;83(3):460-70.
15. Takeuchi F, McGinnis R, Bourgeois S, Barnes C, Eriksson N, Soranzo N, Whittaker P, Ranganath V, Kumanduri V, McLaren W, et al. A genome-wide association study confirms VKORC1, CYP2C9, and CYP4F2 as principal genetic determinants of warfarin dose. PLoS Genet. 2009;5(3):e1000433.

16. Caldwell MD, Berg RL, Zhang KQ, Glurich I, Schmelzer JR, Yale SH, Vidaillet $\mathrm{HJ}$, Burmester JK. Evaluation of genetic factors for warfarin dose prediction. Clin Med Res. 2007:5(1):8-16.

17. Scott SA, Khasawneh R, Peter I, Kornreich R, Desnick RJ. Combined CYP2C9, VKORC1 and CYP4F2 frequencies among racial and ethnic groups. Pharmacogenomics. 2010;11(6):781-91.

18. Sconce EA, Khan TI, Wynne HA, Avery P, Monkhouse L, King BP, Wood P, Kesteven P, Daly AK, Kamali F. The impact of CYP2C9 and VKORC1 genetic polymorphism and patient characteristics upon warfarin dose requirements: proposal for a new dosing regimen. Blood. 2005;106(7):2329-33.

19. Klein TE, Altman RB, Eriksson N, Gage BF, Kimmel SE, Lee MT, Limdi NA, Page D, Roden DM, Wagner MJ, et al. Estimation of the warfarin dose with clinical and pharmacogenetic data. N Engl J Med. 2009;360(8):753-64.

20. Garber M, Hanusa BH, Switzer GE, Mellors J, Arnold RM. HIV-infected African Americans are willing to participate in HIV treatment trials. J Gen Intern Med. 2007:22(1):17-42.

21. Whitley HP, Fermo JD, Chumney EC, Brzezinski WA. Effect of patient-specific factors on weekly warfarin dose. Ther Clin Risk Manag. 2007;3(3):499-504.

22. Burian M, Grosch S, Tegeder I, Geisslinger G. Validation of a new fluorogenic real-time PCR assay for detection of CYP2C9 allelic variants and CYP2C9 allelic distribution in a German population. Br J Clin Pharmacol. 2002;54(5):518-21.

23. Aomori T, Yamamoto K, Oguchi-Katayama A, Kawai Y, Ishidao T, Mitani Y, Kogo Y, Lezhava A, Fujita Y, Obayashi K, et al. Rapid single-nucleotide polymorphism detection of cytochrome P450 (CYP2C9) and vitamin K epoxide reductase (VKORC1) genes for the warfarin dose adjustment by the SMart-amplification process version 2. Clin Chem. 2009:55(4):804-12.

24. Kudzi W, Dodoo AN, Mills JJ. Characterisation of CYP2C8, CYP2C9 and CYP2C19 polymorphisms in a Ghanaian population. BMC Med Genet. 2009;10:124

25. Allabi AC, Gala JL, Desager JP, Heusterspreute M, Horsmans Y. Genetic polymorphisms of CYP2C9 and CYP2C19 in the Beninese and Belgian populations. Br J Clin Pharmacol. 2003;56(6):653-7.

26. Vargens DD, Damasceno A, Petzl-Erler ML, Suarez-Kurtz G. Combined CYP2C9, VKORC1 and CYP4F2 frequencies among Amerindians, Mozambicans and Brazilians. Pharmacogenomics. 2011:12(6):769-72.

27. Scott SA, Jaremko M, Lubitz SA, Kornreich R, Halperin JL, Desnick RJ. CYP2C9*8 is prevalent among African-Americans: implications for pharmacogenetic dosing. Pharmacogenomics. 2009;10(8):1243-55.

28. Scott SA, Edelmann L, Kornreich R, Desnick RJ. Warfarin pharmacogenetiCs: CYP2C9 and VKORC1 genotypes predict different sensitivity and resistance frequencies in the Ashkenazi and Sephardi Jewish populations. Am J Hum Genet. 2008;82(2):495-500.

29. Huang SW, Chen HS, Wang XQ, Huang L, Xu DL, Hu XJ, Huang Z Z, He Y, Chen KM, Xiang DK, et al. Validation of VKORC1 and CYP2C9 genotypes on interindividual warfarin maintenance dose: a prospective study in Chinese patients. Pharmacogenet Genom. 2009:19(3):226-34.

\section{Submit your next manuscript to BioMed Central and we will help you at every step:}

- We accept pre-submission inquiries

- Our selector tool helps you to find the most relevant journal

- We provide round the clock customer support

- Convenient online submission

- Thorough peer review

- Inclusion in PubMed and all major indexing services

- Maximum visibility for your research

Submit your manuscript at www.biomedcentral.com/submit
Ciomed Central 